\title{
기후변화와 공적개발원조(ODA)
}

\section{이 유 진 / 녹색연합 에너지 기후변화 팀장}

I . 들어가며

- 지구와 우리의 운명을 바꿀 기후변화

지난 100 년 동안 지구의 온도는 0.74.다가 올랐다. 1 도 가 채 안 되는 온도 상승은 자구의 기후체계를 변화시 켰다. 세계 곳곳에서 홍수, 폭우, 폭설, 폭염, 슈퍼태풍 과 같은 기상재해가 발생하고 있다. 지금처럼 자구의 온도가 계속해서 오르면 2020년경에는 어떤 현상이 발생할끼? 작게는 4억 많게는 17억 명이 물 부족에 시 덜린다. 야생동물들 중에서 온도 변화에 민감한 개구 리, 뱀, 냉꽁이와 같은 양서파충류는 멸종하게 되고, 식량부조과 전염병이 창결하게 된다. 앞으로 11 년 뒤 에 번이진 인들이다.

이 모든 변화의 원인은 바로 인간의 경제활동, 시구 66 억 인구의 '일상생횔' 이다. 물건을 생산 · 소비하는 과 정에서 사용한 에너지, 운송과 이동을 위해 사용한 에
너지, 냉방과 난방을 위해 사용한 에너지 등 화석연료 를 에너지로 사용하면서 배출한 이산화탄소가 기후재 앙을 일으키고 있다.

기후변화는 누구도 부정할 수 없는 명배한 '사실' 이다. 기후변화에 관한 정부간협의체 (Intergovernmental Panel on Climate Change: IPCC)는 2007년 '제 4차 기후변화 평가보고서'를 통해 '기후 체계의 온난화는 의심의 여지가 없는 사실 (unequivocal)' 임을 명백하게 밝혔다. 뜨한, "시구온난 화 의 진행속도는 2001 년 발표된 3 차 보고서의 에측 치를 넘어서 예상보다 빠르게 진행되고 있다고 경고힜 다. IPCC 실무그룹1의 기후변화과학부문 보고서에 따 르면 온실가스의 대기 중 농도는 산업혁명 이전 $280 \mathrm{ppm}$ 에서 2005 년 $379 \mathrm{ppm}$ 으로 증가하였다. 이로 인해 지난 100 년간(1906 2005년) 지구평균온도는 0.74 도(0.56 0.98도) 상승하고, 자구 평균 해수면은 1961 2003년 사이에 $1.8(1.3 \sim 2.3) \mathrm{mm} /$ year 상승했 
다. 자구온난화 전망에 대한 6가지 시니리오 작업을 통-해 화석연료에 의존한 대량소비형의 사회가 계속된 다면, 1980 1999년에 비하여 금세기말(2090 2099 년)의 자구 평균기온은 최대 6.4 , 해수면은 $59 \mathrm{~cm}$ 상승 한다고 전망하였다. 지구와 지구에서 산아가는 우리 모두의 운명은 지구의 온도상승을 어느 수준에서 막을 수 있는가와 변화하는 기후에 잘 적응해서 살아남을 수 있는 방법을 제대로 준비하는가에 달려있다.

이 글은 기후변화와 공적기발원조(ODA)에 대해 다루 고 있다. 기후변화가 워낙 광범위하게 진행되는 일이 라 최근 기후변화와 건강, 기후변화와 경제, 기후변화 와 자연재해, 기후변화와 여성 등 기후변화를 중심에 두고 다양한 주제들에 대한 연구가 진행되고 있다. ODA와 빈긴문제도 기후변화와 연관을 가질 수밖에 없다. 우리는 2000년 9월 UN 총회에서 의절한 밀레 니임 신언의 결의를 잊어서는 안 된다. 밀레니임 신언 은 2015년까지 전 세계 절대 빈곤층을 절빈수준으루 줄이고 개도국의 빈곤퇴치와 지속가능한 발전을 위해 8 개의 목표와 18 개의 세버목표를 제시한 것이다. 2002년 'UN 개빌재원 정상회의' 는 선진국이 국민총 생산 대비 ODA를 $0.7 \%$ 까지 확대할 것을 노력하기로 걸의한바 있다. 빈곤퇴치를 기치로 내건 밀레니엄 선 언은 전 세계에서 가속화되는 기후변화에 의해 달성 가능성이 영향을 받을 수밖에 없다. 기후변화가 ODA 를 통해 돕고자 하는 사람들의 삶을 다욱 페폐하게 만 들고 있기 때문이다. 가장 가난한 니라일수록 기후변 화가 가저오는 충격을 더 빨리, 더 심각하게 받을 가능 성이 높다. 기후변화에 대처하거나 충격을 피하는데 필요한 자원을 적게 보유하고 있기 때문이다. 이것은
$\mathrm{ODA}$ 를 위한 다양한 노력과 전락들이 기후변화로 인 해 한순간에 무너질 수도 있다는 이야기이다. 기후변 화시대 우리는 $\mathrm{ODA}$ 를 둘너싼 전략을 새롭게 짜야 하 며, 대외원조의 패러다임 자체를 바뀌야 한다. 지금까 지 개도국에서 이뤄지는 개발사업이 환경문제를 간과 해 왔다면 이제는 달라저야 한다.

\section{II. 기후정의 - 기후변화 최초의 희생자들}

지난해 12 월 인도네시아 발러에서 열린 '제13차 기후 변화협약당사국 총회 장에서 우르술라 라코바(43)씨 를 만갔다. 그녀는 남태펑양의 작은 섬 카트레츠 출신 이다. 600 가구 3 천 명의 주민이 살고 있는 카트레츠에 선 기후변화가 몰고 온 파국의 징후를 피부로 느낄 수 있다. "여기 있는 사람 대부분이 카트레츠라는 섬에 대 해 처음 들어봤을 텐데요. 남태평양 부건빈(파퓨아뉴 기니령)에 속하는 6 개의 작은 섬을 통칭해 카트레츠라 고 합니다. 몇 해 전 섬이 하나 더 생겨서 사금은 7개가 됐어요. 두 개의 봉우리로 연결돼 있던 섬 중간에 바닷 물이 차올라 하나였던 섬이 2 개가 돼버렸답니다." 라 고바는 "이미 20년 전부터 섬에 물이 차오르기 시작해 농사를 전혀 시을 수 없게 됐다."며 "주민은 짜서 마실 수 없는 물 내신 코코넛을 바신다."고 말했다. "지난 43년 동안 단 한 번도 섬을 띠난 적이 없었다."는 라코 바씨는 "아침에 코코넛 니무가 해안에 쓰러져 있는 것 을 볼 때마다. '이제 정말 시간이 얼마 남지 않았구나.' 하는 생각을 한다."고 했다. 지난 20년간 제방도 쌍아 봤지만, 무심한 파도는 늘 제방을 송두리째 삼켜버렸 


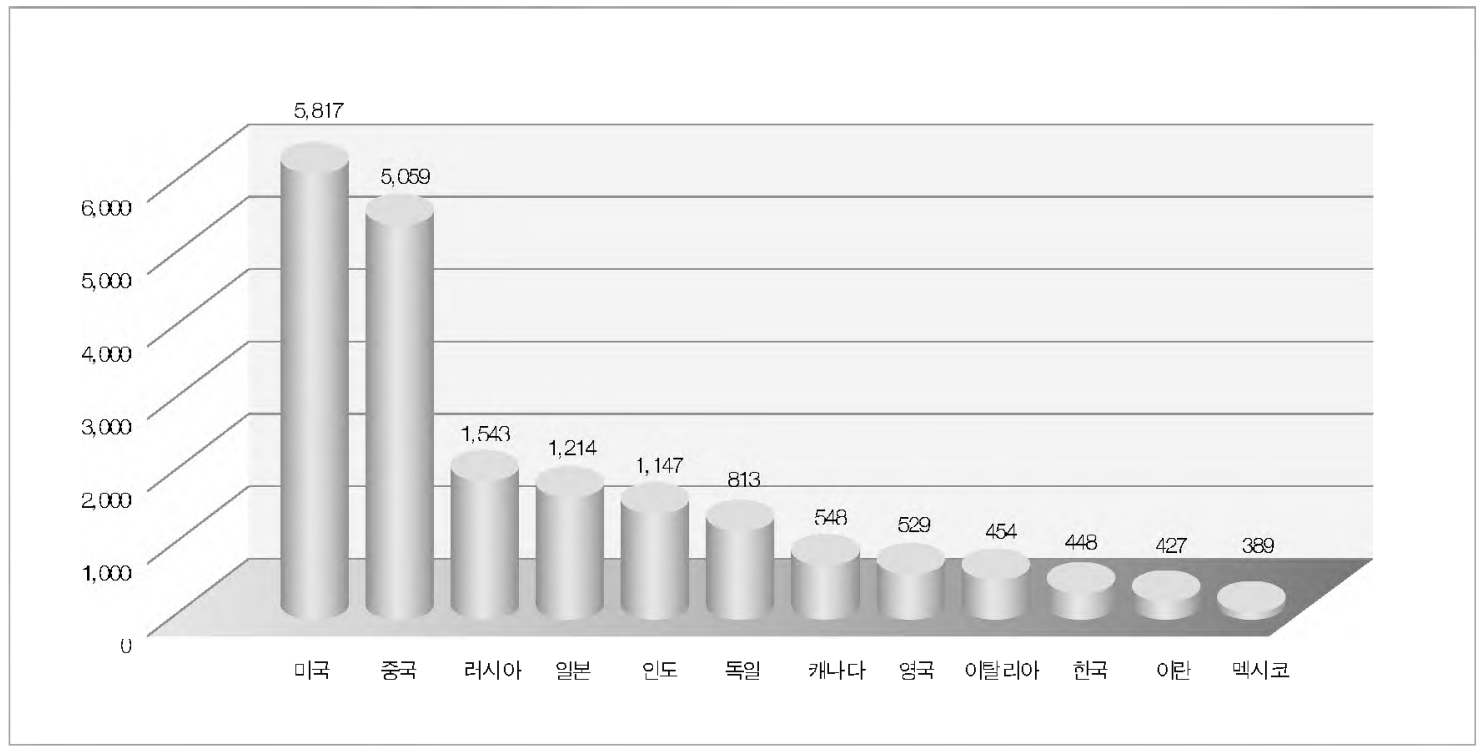

※ 출처: 4차 기후변화종합대책.

단다. 그에게 다가가 밀을 걸어봤다. "카트레츠에는 차 가 멏 대나 있어요?" "차, 없어요. 우리 섬에서 차를 몰 면 쭉 가다가 바다에서 산호초를 들이받을걸요." "그 럼 전기는?" "전기도 없어요." "어, 그럼 텔레비전도 컴퓨터도 없겠네요." "없어요." "다른 섭이랑 연락은 어떻게 해요?" "카누 타고 가지오." "이렇게 회의에 참 가하려면, 당신한테 연락을 해야 하잖아요." "아, 부건 빌 옆에 카트레츠보다 좀 더 는 섬이 있어요. 그 섬이 랑 태양광 무전기로 교신을 해요." 불어나는 물, 낫아 지기만 하는 해수면, 섬 주민 모두 부건빌로 이주하는 것만이 유일한 희망이다. 그러나 돈이 없다. 주민 3 천 명이 모두 부건빌로 이사하는 데 드는 비용은 우리 돈 으로 55억 원 정도가 필요하난다. 강남 아파트 멏 채면
수장당하기 직전인 이 작은 섬 주민들의 생명을 구할 수 있다. 라코바는 이번 회의에시 "기후변화의 피해자 들이 직접적인 지원을 받을 수 있으면 좋겠다." 고 강조 했다. 회의 결과를 보면, 안타깝게도 카트레츠 같은 '위기의 땅' 이 구,제사회의 지원을 받기까지는 더 많은 시간이 건릴 것으로 보인다.

기후 변화는 글로벌 현상이기는 하지만, 그 결과는 카 트레츠선의 운명처럼 균등하게 배분되지 않는다. 빈국 과 작은 섬나라들이 가장 먼저, 가장 심하게 타격을 받 게 될 것이다. 리서치 회사인 메이플그로프트가 전 세 계 189 개국을 대상으로 기후 변화로부터 영향을 받는 정도를 수치로 산출해 만든 보고서에 따르면 ${ }^{2}$, 개발도

1)세계 각국의 지험, 인구, 환겸, 낱씨 변화 듬의 자료를 분서해 기후 변회 지수(CCl,Gima.e Change Index)를 산출하고, 기후변회에 엽향을 많이 받을 나라 의 순위를 매긴 결과. 
〈그림 2〉탄소배출 지도

\section{World by Carbon Emissions $\quad$ size ofa country \\ equals emisgions \\ in inilion metric tons}

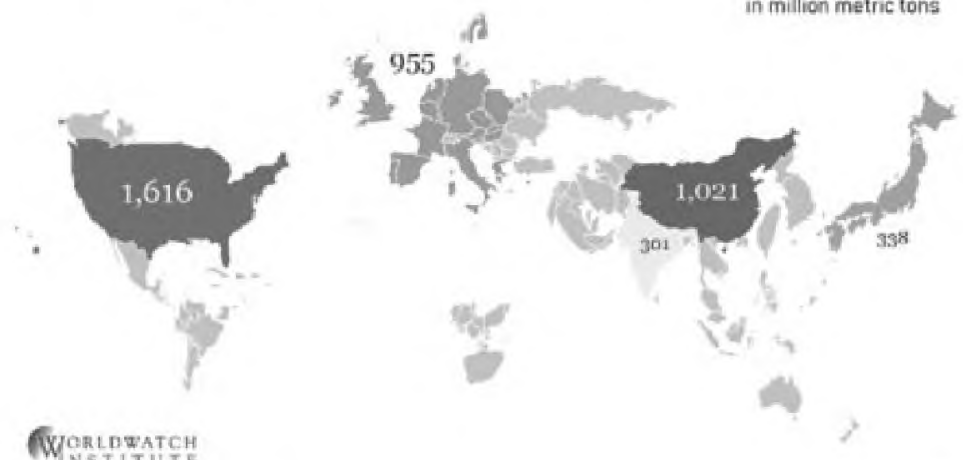

WWORLDATCH

5 Woridwabch Institute, 2006

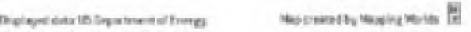

※ 출처: 월드워치연구소

〈그림 3〉 기후변화취야ㅅㅓㅓ 지도

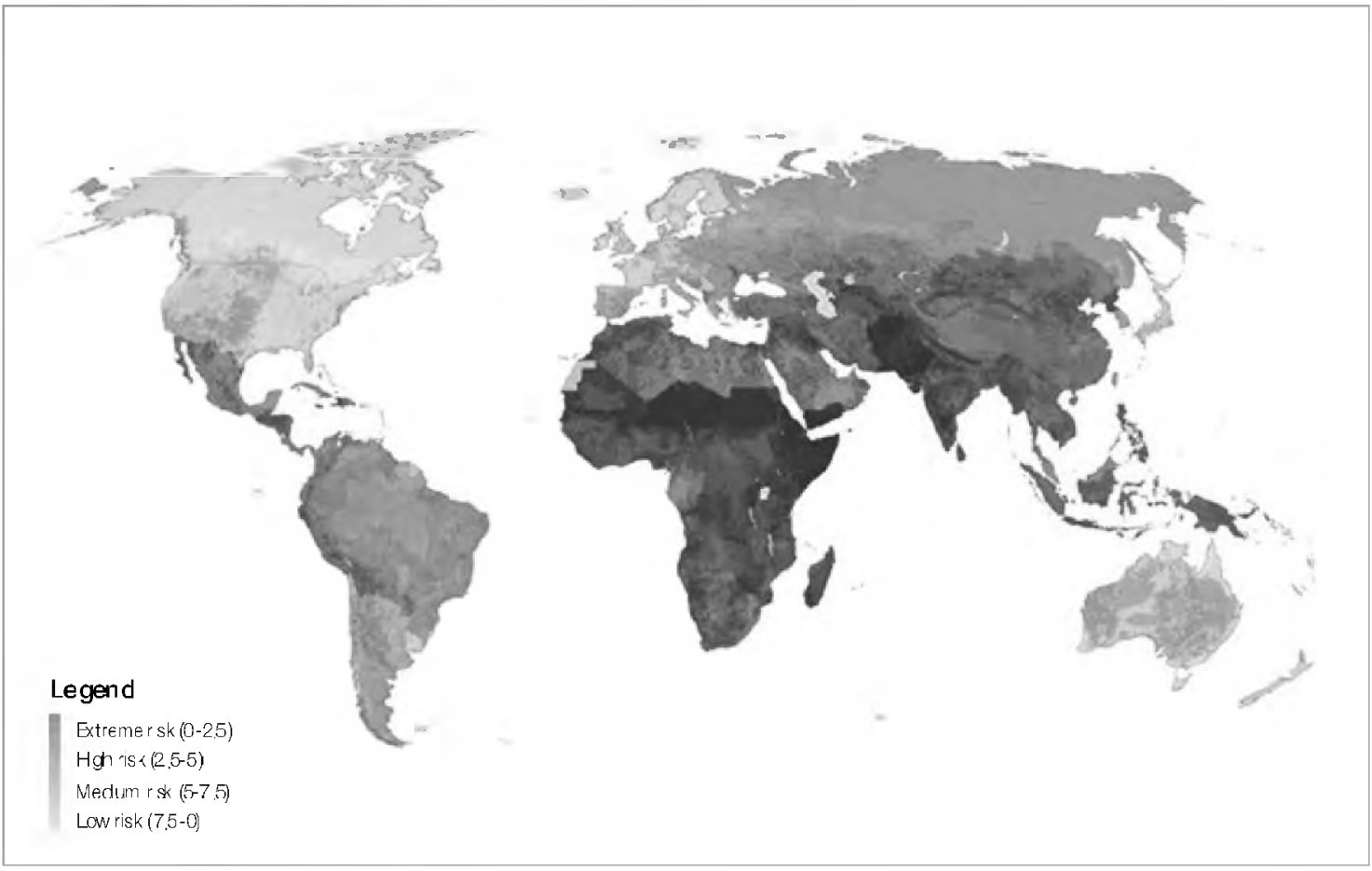

※ 출처 : 메이프크로프느 
상국과 저기발국이 기후 변화의 위험에 고스란히 노출 돼 있는 것으로 밝혀 졌다. 0 에 가까울수록 위협을 많 이 받는 것으로 나타난다. 가장 타격을 크게 받을 나라 는 아프리카 지부티(0)와 이집트(0), 안전한 나라는 동 유럽의 아르메니아(10), 키르키스탄(10), 마케도니아 (10)로 나타났다. 지도에서 보면 파란색에 가까울수록 기후변화에 취약한 시역을 나타낸다.

그림에시 왼쪽에 있는 탄소발생량을 각국의 면적-으루환산해 새로 작성한 탄소지도와 취약성지도는 정반대 의 양상을 보여준다. 온실가스를 많이 배출하시 않아 면적이 적게 표시된 아프리카와 아시아가 기후변화에 매우 취약하다는 것을 나타낸다. 지도를 비교해보면 온실가스를 엄청나게 배출하는 미국과 유럽니라 사람 들이 보이지 않는 망치로 이집트와 지부터 사람들의 집을 내려치는 것과 같은 결과를 낳는다는 사실을 알 수 있다. 폭우와 홍수, 가뭄, 폭염 등의 빈빌과 같은 극 딘적 기후 사긴든은 인간의 생명을 위태롭게 하고 있 다. 그 피해를 세계의 가난한 사람들이 특히 극지방과 태평양 한가운데 있는 섬사람들이 가장 먼서 당하고 있다.

세계보건기구(WHO)는 2008년 세계 보건의 날 데마 를 기후변화' 로 설정했다. $\mathrm{WHO}$ 는 '기후변화로버-터 건강 보호'를 동해 기후변화로 인한 사망자가 세계적 으로 연간 16 만 명에 달한다고 반표헸다. 기후변화와 관련된 폭염, 자연재해, 전염병으로 인한 사망자를 추 산한 것이다. $\mathrm{WHO}$ 는 기후 변화가 건강에 미쳐온 주 요 영향을 5 가지로 정리했다. 첫째는 식량위기로 인한 기근이다. 기후변화에 극히 민감한 농업 부문에서 기

온의 증가와 더욱 잦은 가뭄과 홍수로 인해 식량 안보 가 위협에 처하게 되고, 그에 따라 영양실조가 증가하 게 된다는 것이다. 현재 영양실조 사망사는 연간 350 만 명으로 추산된다. 둘째는 극단적인 기후 재난으로 인한 인명피해이다. 동시에 홍수로 인해 상하수도 시 설이 훼손되었을 때 콜레라와 같은 질병들이 발병하게 된다. 2005년 허리케인 카트리나로 인해 1,800명 이 상이 숨지고 수천 명의 이재민이 발생했으녀, 피해 지 역의 보긴 시설들이 완전히 파괴되었다. 방글라데시에 서는 홍수로 오염된 물이 콜레라를 유발했다. 셋째로 물 비족이나 폭이로 인한 물의 과잉 모두 오혐된 물과 음식을 동해 확산되는 설사성 질병을 증가시키게 된 다. $\mathrm{WHO}$ 에 따르면, 설사성 질병으로 인한 사망자는 연간 약 180 만 명에 이르며, 설사성 질병은 아동 사망 원인 중 2 위를 차지하고 있다. 넷째로 도시의 폭염이 다. 십장 및 호흡기 질한을 지닌 노인층을 중십으로 직 접직으로 질병과 사망이 증가하고 있다. 2003년 여름 유럽을 강타헸던 폭염으로 인해 당초 예상보다 훨씬 많은 7만 명이 숨졌다. 폭염 이외에도 기온의 증가는 시표면의 오존을 증가시키고 꽃가루 발생 시기를 앞당 김으로써 천식을 유빌시키고 있다. 다싯째로 기온 및 강우 패턴의 변화는 질병을 매개로하는 동문 분포의 변화를 가져올 것이다. 질벙 가운 데는 말라리아와 댕 기열이 가장 큰 위험 요소로 평가된다. 동아프리카 고 원 지내의 경우 지난 30 년간 기온이 지속적으로 증가 하면서 모기의 수가 크게 늘이났고, 그 견과 만라리아 의 확산이 이뤄졌다. 이외에도 해수면 상승이나 빙하 가 눅아내림으로 인해 직접적으로 생명을 잃는 경우도 발생하게 된다. 
지구온난화로 일어나는 기상현상인 가뭄, 홍수, 물부 족, 지하수 고갈, 사막화, 수질오염은 빈건의 심화와 바로 연결된다. 극단적인 기상현상이 농업생산량에 영향을 미치기 때문이다. 또한 인도네시아 쓰나미, 미 얀마의 슈푀태풍 등 긴급구호를 해야 할 상횡들이 점 점 더 증가할 것이다. 실제 이런 상황이 벌써 발생하 고 있다.

유엔 기후변화 정부간 위원회(IPCC)가 지난 1998년에 내놓은 보고서를 보면, 해수면이 $1 \mathrm{~m}$ 상승할 때마다 방 글다데시에선 300난ha의 땅이 물에 잠기면서 1,500 만 2,000만 명의 이재민이 발생할 것으로 전망된다. 베트님에신 전국직으로 약 250만ha가 물에 잠기면서 1,000 만 명의 이재민이 날 것으로 예상된다. 또 인도 양의 섬나라 몰디브는 본섬의 $85 \%$ 가 물에 잠기면서 약 30 만 명의 난민이 인도와 스리랑카 등 인근 구갈로 이주할 것이라고 $\mathrm{IPCC}$ 는 내다봤다. 급격한 기후변화 로 세계적으로 환경난민이 대거 발생하는 것이다. 사 하라이남 아프리카에서는 남자와 여자, 어린이의 3 분 의 1 이 이미 영양실조에 걸녀 있다. 여기에 기후변화가 닥치면 식량생산이 $20 \%$ 감소할 것으로 예측된다. 탄 자니아는 기온이 상승하고 우기가 짧아지면 주식인 옥 수수 수확량이 3 분의 1 줄어든다. 걸국 더 많은 사람이 더 굶주리게 되는 것이다.

그래서 기후변화협약당사국 총회에서는 자금까지 온 실가스를 배출한 선진국들의 '역사적 책임' 을 강조하 고 있다. 또한 ‘공동의 차별화된 책임’ 으로 기후변화 에 내해 모든 나라가 예외 없이 노륵 하되 각 국의 경 제적 상황과 역사적 책임에 따라 행동해야 한다는 목
소리가 높다. 국제사회는 2008년과 2009년 논의를 통 해 2013년 이후 온실가스 의무감촉 대상국과 감축 목 표를 설정할 예정이다. 하시만 여기 서도 선진국과 개 도국의 입장은 평행신을 달리고 있다. 선진국들은 온 신가스 감축을 하는데 Annex I 국가를 비롯한 선진국 들의 노력만으로는 한계가 있는 것이니 개도국들도 동 참을 해야 한다는 입장인데, 개도국들은 역사적인 책 임 등을 이유로 선진국들이 기술이나 재원 등을 바련 해야 한다는 주장이다. 또한 선진국들이 가지고 있는 ODA와 별도로 GNP의 $0.5 \sim 1 \%$ 를 추가로 기후변화 대 응을 위한 개도국 시원 사금으로 제공해야 한다는 주장 을 하고 있다.

\section{III. 기후변화와 대외원조를 둘러싼 쟁점들}

IPCC는 기후변화로 인한 피해의 임계점을 넘기지 않 기 위해서는 지구온도가 2도 상승하는 선에서 멈춰야 한다고 이야기한다. 느렇게 하기 위해서는 시구상의 온실가스 농도가 $450 \mathrm{ppm} \mathrm{CO2 \propto q}$ 아상이 되어서는 안 된다. 캐나다의 환경운동가 조지 몬비오는 2030년까 지 지구온난화의 원인이 되는 온실가스 배출랑을 $90 \%$ 감축해야 한다고 주장한다. 가장 적극적으로 온실가스 감축 목표치를 제시하고 있는 영국의 2050년까지 $60 \%$ 감축보다 횔씬 높은 목표치이다. 목표를 삼은 기 준은 오로지 지구 평균기온이 산업혁명 이전보다 2도 이상 현재보다 1.4 도 이상 상승하지 않도록 하는데 있 다. 2030 년 온실가스 농도를 현재 수준으로 유지하기 위해서는 세계 인구가 1 년에 27 익 톤 이상을 배출해서 
는 안되며, 1 인당 탄소 배출랑이 0.33 톤을 넘어서는 안 된다. 따라서 1 인당 2.6 톤을 배출하는 영국은 배출량 을 $87 \%$ 감축해야 한다. 같은 계산으로 현재 1 인당 3.34 톤을 배출하는 우리나라는 $90 \%$ 를 감추해야 한다. 빈면 1 인당 0.33 톤이 안 되는 나라는 배출이 늘이나도 된다. 그가 볼 때 유엔기후변화협약(UNFCCC)의 교토 협약에서 제시한 2012 년까시 $5.2 \%$ 감축은 너무 적은 양일 수밖에 없다. 이것은 전 세계의 정치적, 경제적, 사회적 의지와 자원이 기후변화를 막기 위한 다양한 활동에 집중되어야 한다는 것을 의미한다. 그렇다면 기후변화시대 국제사회 $\mathrm{ODA}$ 의 흐름은 어떻게 형성되 고 있으녀, 어떤 내안이 필요한 것일까. 또한 기후변화 와 이로 인한 빈곤문제 해결을 위한 재징지원은 어떤 철학과 원칙을 가져야 하는 것일까.

\section{1. 환경분야의 $\mathrm{ODA}$ 증액}

일반적으로 $\mathrm{ODA}$ 는 수원국에서 요청을 해야 하는데, 현재로서는 수원국에서 당장의 '빈긴퇴치' 나 '개발' 이 아닌 '환경' 이나 '기후변화 대응' 에 관한 시원을 요청 하는 경우가 드물다. 하지만 기후변화 문제가 짐짐 더 심각해지고, 이로 인해 장기적으로 저개발국의 환경과 경제가 더욱 악화되고 있다는 인식이 확산됨에 따라 상황은 바뀌게 될 것이다. 따바서 각 국가의 $\mathrm{ODA}$ 에 있 어서 환경 분야에 내한 증액이 필요하다.

노르웨이는 자발적으로 기후변화 방지와 관련한 신규 $\mathrm{ODA}$ 프로젝트 추진을 준비하고 있다. 노르웨이 환경
부장관은 $\mathrm{ODA}$ 업무를 관장하는 국제기발부장관도 검 직하고 있다. 노르웨이의 $\mathrm{ODA}$ 규모는 국민총소득 (GNI)의 $1 \%$ 가량으로, 스웨덴과 더불어 GNI 대비 원 조비율이 세계에서 가장 높다. 노르웨이는 전 세계 탄 소배출량의 $20 \%$ 는 얼대우림과 신림파괴에서 비롯된 다고 판단하고, 브라질과 콩고, 인도네시아 같은 국가 들이 열대-우림을 훼손하시 않고 보존할 경운 노르웨이 정부가 내년 6 어 달러씩 향후 5 년간 총 30 억 달러(약 3 조원)를 지원할 계획을 세우고 있달.

형국 정부는 시난 2월 환경보호를 통한 개발 및 빈곤 감소를 지원하고 개발도상구들이 기후변화에 대응하 는 것을 돕기 위해 앞으로 5 년 동안 10 익 파운드 규모 의 기금을 조성한다고 발표했다. 영국정부의 국재게 발관인 더글라스 알렉산더는 "기후변화는 지금까지 개도국의 빈곤을 해걸하기 위한 모든 노럭을 거품으로 만들어버릴 수도 있으며, 이젓은 자구직 사회징의 문 제이다. 따라서 개발과 기후변화문제가 연결되어 있다 는 것에 주목해야 한다."라고 주장했다. 영국정부는 7 천5백만 파운드를 우선적으로 기후변화 적응기금에 시용될 것이라고 빍헜다. 2007년 영국징부는 이미 개 도국에 재생가능에너지를 보급하는데, 8억 파운드의 기금을 조성하기로 발표한 바 있다.

세계자연보호기금(WWF)은 세계은행(WB)를 비롯한 유엔 산하 16 개 기구에서 온신가스 감축 및 지구 온난 화로 발생할 수 있는 가뭄, 홍수, 해수면 상승 저지를 위해 자금을 지원하고 있지만 필요한 금액에 비해 턱 
없이 부족하다는 언구 걸과를 발표했다 ${ }^{4}$. 특히 최대 빈 긴 대륙이자 기후 변화에 가장 취약한 아프리카 국가 들에 대한 시원이 미비하다고 전했다. WWF에 따르면 개발도상국이 기후 변화에 대처할 수 있도록 신진국들 이 2030 년에는 현재 250 억 달러의 5 배 수준인 1,300 억 달러를 제공해야 한다는 것이다. 따라서 노르웨이 나 영국처럼 환경과 기후변화 분야의 $\mathrm{ODA}$ 를 증액하 는 노럭이 더욱 필요하다.

\section{2. 청정개발메커니즘(CDM)과 ODA}

현재 개도국의 기후변화 내응 지원기금은 유엔 산하 청징개빌체제(CDM)를 통해 조딜되고 있다. $\mathrm{CDM}$ 은 온실가스 배출 삭감을 약속한 선진국이 삭감 의무가 없는 개도국에서 온실가스 감축 프로젝트를 수행하고 감축한 양을 선진국의 감축목표 달성에 활용하는 것이 다. 지난 13 차 기후변화당사국 총회에서는 탄소배출권 기래에서 $2 \%$ 씩 조성한 기금을 개도국의 기후변화 적 응 사업에 쓰기로 하고 지구환경기금(GEF)을 관리 주 체로 결정하면서, 앞으로의 재원 마련을 위해 탄소세 부과 등의 다양한 방법을 논의하기로 했다. 뜨한 개도 국이 자국의 상림황폐를 막는 조림사업을 진행하면 선 진국이 인센티브를 부여하기로 했으며, 기존의 산림을 벌목하시 않고 보전하는 행위에 대해서는 어떻게 보상 할 것인지에 내해 논의하기로 했다.

그러나 기후변화 대응 지원 기금을 CDM에 지나치게 의존하는 구조에 대해 우려의 목소리가 높다. CDM 조
성의 원칙에는 '기발도상국의 지속가능한 기발 목표 에 부합할 것', 개도국이 프로젝트로부터 이읙을 얻 을 것 이라는 조건을 달고 있다. 선진국은 적은 비용으 로 온실가스를 줄일 수 있고, 개도국은 선진국의 자금 과 기술로 자국에 도움이 되는 프로젝트를 하는 것이 다. 물론 선진국이 초기에 시행하기 쉬운 대책만 개도 국에서 진행하고, 삭감량을 가셔가 버리면 개발도상국 이 나중에 삭감을 하려고 해도 나중에는 어려운 대책 만 남는다는 비판도 있다. 또 민간에서 추진하는 CDM 사업들이 중국이나 인도 등 사업타산성이 높은 신흥국 에 집중되는 헌상이 벌어셔 개선이 필요하다는 시적도 있다. 기업들이 온실가스 방출량 자체가 적은 아프리 카 국가들에 투자하는 것을 끼리기 때문이다. 실제로 2006년 전 세계 CDM 사업 현황을 보면, 아태지역 206 개, 남미지역 207개, 아프리카 11개로 아프리카에 대한 투자가 배우 적다는 것을 알 수 있다. 빈곤국가는 산입 인프라가 없기 때문에 배출권 거래제도가 실질직 인 도움이 되지 못한다.

또 하나 눈쟁이 되는 것은 $\mathrm{ODA}$ 를 $\mathrm{CDM}$ 사업에 사용 할 수 있는가 여부이다. 2004년 OECD 개빌원조위원 회 (DAC)는, $\mathrm{ODA}$ 를 $\mathrm{CDM}$ 감축신적 $(\mathrm{CER})$ 을 확보하는 데 사용될 수 없다고 걸정하였다. 게발원조가 CDM 분 야로 집중되면 교육과 위생 등 온실가스 감축과는 관 련이 없는 프로젝트가 줄어들 가능성이 있다는 것이 다. 그러나 인본은 꼻임없이 $\mathrm{ODA}$ 자금을 $\mathrm{CDM}$ 프로 젝트에 이용할 수 있어야 한다고 주장하고 있다. 일본 은 2005년 ODA 전략을 바꾸면서 교토이니셔터브를

4) 연합뉴스, $2008,08,28$, 
설정했다. 교토의정서에 따라 온실가스를 의무적으로 감축해야 하는 일본으로 서는 $\mathrm{CDM}$ 사업에 집중하면서 개도국의 역량강화사업을 결합시킨 것이다. 시구환경 전략연구기관(IGES)의 히라이시 타카히코 연구원은 상호협력적 $\mathrm{CDM}(\mathrm{Co}$-benefit $\mathrm{CDM})$ 을 제시하고 있 다. $\mathrm{ODA}$ 프로젝트에서 온실가스 감축을 동반하는 프 로젝트로 1)중장기적인 시원, 2)에너시 자원의 효율적 인 활용과 주변 환경 개선, 3)생활의 질적 향상을 사업 의 중심 목표로 삼고 자금 기빈을 CDM으로 확보하는 방법을 제시하기도 했다. 그는 상호협력적 $\mathrm{CDM}$ 을 실 현하기 위해 온실가스 감축과 더불어 수원국의 시속가 능한 개발에 공헌했는가를 정량적으로 평가하는 시스 뎀을 갖취야 한다고 주장한다.

$\mathrm{ODA}$ 의 $\mathrm{CDM}$ 사업 사용 여부는 앞으로 더 논의가 필 요할 것으로 보인다. 현재 환경이나 기후변화에 대한 $\mathrm{ODA}$ 투자가 너무나 부좋하기 때문에 이것이 유인이 될 수도 있다는 주장도 있다. 다만 ODA도 지원하고 $\mathrm{CER}$ 도 얻는 '뀡먹고 알먹는' 식의 관점으로 접는하는 것은 안된다. 원조의 철학과 원칙은 개도국의 빈곤타 파와 지속가능한 빌전에 있다는 것을 우선시 한다면, 그것으로 수익구조를 얻는 방식에 집착해서는안 된다 는 것이다. 그런 의미에서 '상호협력적 $\mathrm{CDM}$ ' 에 대해 서도 더 많은 눈의가 필요할 것으로 보인다.

\section{3. 수원국에 꼭 필요한 도움을}

공여국은 MDGs 목표와 기후변화대응을 위한 ODA의
원칙을 세우고 수원국에 꼭 필요한 도움을 줄 수 있어야 한다. 기후변화 대응은 특히 그 지역의 기상정 보와 국토 의 특성, 사람들의 생할양식과 밀접하게 관련이 되어 있 기 때문에 공여국의 일방직인 사업추진과 집행이 아닌 수원국과의 긴민한 협력이 다욱 중요하다. 수원국이 꼭 필요한 도움을 지원해 줄 수 있어야 한다는 것이다.

기후변화내응 정책에서 중요한 것은 여시 사회적 안전 망 문제이다. 2004년 9월 강력한 허리케인이 중남미 에 연달아 불어 닥쳤을 때, 아이티에서는 3 천명이 홍 수로 익사했시만 쿠바에서는 단 한명의 사망사도 발생 하지 않았다. 쿠바도 가난한 나라이지만 지역사회에 기반을 둔 재난대비 시스템을 갖추고 있다. 피델 카스 트로가 장장 다섯 시간 동안 허리케인이 다가오고 있 다는 생방송을 했다. 기후변화 적응 방안에는 에방, 초 기 대응, 호율적 사후처러가 있다. 예방조치로 폭연이 나 기상재해와 깉은 자연재해에 관한 조기경보시스템 과 기후변화에 취약한 계층을 대상으로 한 사전예방 정책을 펼쳐야 한다.

방글라데시도 기후변화대응을 위한 태풍경보시스템을 갖췄다. 세계기상기구의 발표에 의해 폭풍이 임박힜다 고 판단되면, 자전거를 탄 안전요원들이 호루라기를 불며 이 사실을 시역주민들에게 알리고 다닌다. 시역 주민들은 훈련받은 내로 즉시 고지내나 비러 바련된 대피소로 이동힌다. 이러한 대응 으로 최근에는 태풍의 위력이 강해지는데도 불구하고 사망률은 오히려 감소 하고 있닿․ 이처럼 기후변화대응은 온실가스 감축 분

5)가브리엔 워커, 데이비더 킴. [핫 토픽 - 기후변회 샘즌과 대음전략], 92 쪽, 2008. 
야도 있지만 적응 분야가 중요하다. 온실가스 감축을 위한 기술적 기계적 설치나 시설지원 보다는 농사를 망칠 수 있는 혹서비터 해수면 상승에 대비해 실질적 으로 생존의 조건을 마련하는 적응 분야에 대한 투자 가 더 시급하다고 할 수 있다. 기후변화로 인해 개도국 이 겪고 있는 문제가 무엇인지 파악하고, 그 지역에 맞 는 적합한 기술과 시스템을 갖춧도록 해야 한다. 여기 에 있어서는 첩단기술보다는 적정기술이 지여에 따라 디 적합 할 수도 있다.

\section{$\mathrm{IV}$. 한국의 $\mathrm{ODA}$ 정책과 기후변화 대응}

우리나라는 ODA를 받던 나라에서 이제 원조를 하는 나라로 탈바꾼 했다. 세계적으로 드문 사례이다. 우러 나라는 1991년 한국국제협력단(KOICA)이 설립되면서 원조 공여국으로 전환되었다. 우리니라의 대외원즈 구 심축은 외교통상부와 $\mathrm{KOICA}$ 는 무상원조를 기반으로,
지식경제부와 수출입은행은 유상원조를 담당하는 두 축으로 형성되었다 우리나라의 국민총소득 $(\mathrm{GNI})$ 대 비 대외원조 규모는 1991년 1.1억 달더에서 2007년 잠 징 규모 6.7 익 달러 $(0.07 \%$ )로 증가했다. 그러나 $\mathrm{OECD}$ 개발원조위원회(DAC) 평균 $0.25 \%$ 와 비교하면 매우 적다. 이에 정부는 2005 년 11월 11일 'ODA 개선 종합 대책' 을 수립하고 2015년까시 ODA 규모를 현재의 두 배인 GVI 대비 $0.25 \%$ 수준으로 확대한다는 방친을 밝 혔다. 문론 이 뚜한 UN이 제시한 2010년까지 $0.5 \%$, 2015 년까지 $0.7 \%$ 에 비하면 미미한 수준이다.

대외원조의 구체적인 내용과 형식을 들여다보면 더욱 문제가 심각하다. 대외원조 증액만큼이나 중요한 것은 지원금액이 실제 도움이 되는 곳에 쓰이냐에 있기 때 문이다. 대외원조의 원칙과 목표는 '인도주의 입각', ‘국제사회의 공동과제인 빈곤퇴치와 지속가능한 개 빌'에 있다. 그런데 우리의 ODA는 외교통상부, 유상 원조는 지식경제부로 이원화되어 있으며, 해외원조 에 산부처도 통합 관리되고 있지 않다. 특정 기업군이 전

〈표 1〉우리정부의 ODA 지원 실적

\begin{tabular}{|c|c|c|c|c|c|c|c|c|c|}
\hline 구 분 & 00 & 01 & 02 & ${ }^{\prime} 03$ & 04 & 05 & 06 & ' 07 (잠정) & 총계 \\
\hline 공적개발원조(ODA) & 212. & 264.7 & 278.8 & 365.9 & 423.3 & 752.3 & 455.3 & 671.8 & $4,923.5$ \\
\hline (1) 양자간 협력 & $13^{4} .2$ & 171.5 & 206.8 & 215.2 & 330.8 & 163.3 & 376.1 & 162.1 & $3,166.8$ \\
\hline 무상원조 & 47.8 & 53.0 & 66.7 & 145.5 & 212. & 318.0 & 259.0 & 329.9 & $1,803.5$ \\
\hline$(\mathrm{KOICA})$ & $(43.6)$ & $(47,0)$ & $(58.6)$ & $(-21,8)$ & $(174.6)$ & $\left(20^{-}, 9\right)$ & $(193.1)$ & $(269,5)$ & $(1,444,9)$ \\
\hline ○ 유상원조(EDCF) & 83.4 & 118.6 & 140. & 99.7 & 118.7 & -45.3 & 117.1 & -32.2 & $1,363.3$ \\
\hline (2) 다자간 헙력 & 80.9 & 93.1 & 72.0 & 120.7 & 92.6 & 289.0 & 79.2 & 209.7 & $1,756.7$ \\
\hline ODA/GNI (\%) & 0.04 & 0.06 & 0.05 & 0.06 & 0.06 & 0.10 & 0.05 & 0.07 & \\
\hline
\end{tabular}

6) ODA는 크게 양자간 원조와 다자간 원조로 구분되뎌, 양자간 원조는 다시 자금의 상홤여부에 따라 무상원조와 유상원조로 구분된다. 한국의 무상 ODA 전 체 규노는 200 년 193 백만 달러로 전체 ODA 규노의 $47.8 \%$ 를 차지한다. 
체 사업의 70 80\%를 수주하는 등 원조사업 독점문제 와 비전문성 문제도 지적되고 있다"

2005 년 우리나라 ODA 사업 집행 내역을 보면, 145 백 만 달러에 이르는 유상원조는 기획재정부 감독 하에 수 출입은행(19.5\%)에서, 무상원조인 208 백만 달러는 외 통부 감독 하에 KOICA(28\%)에서, 390백만 달더는 40 개의 지자체 및 정부부처(52.4\%)에서 각각 집행했다. 각 정부부처에서 집행하는 대외원조 비중이 전빈을 넘 고있다. 대외원조의 형식도 구속성 원조가중심이다.

$\mathrm{OECD} / \mathrm{DAC}$ 회원국의 2006년 평균 ODA/GNI는 $0.31 \%$ 이며, 일부 신진 공여국들은 MDGs 달성 목표 시한인 2015년까지 $0.7 \%$ 이상 달성을 공약하였고, $\mathrm{DAC}$ 회원국 대부분이 $0.5 \%$ 수준 달성 예상된다. 우리 $\mathrm{ODA}$ 규모는 구, 제사회의 권고 기준 및 경제럭이 유사 한 여타 공여국의 ODA 제공 수준에 비해 크게 미흡하 다. 2007년 우리나라 ODA/GNI 비율(0.07\%)은 $\mathrm{OECD/DAC}$ 회원국의 $1 / 5$ 로 우리니라 1 인당 $\mathrm{ODA}(10$ 불)는 $\mathrm{DAC}$ 국가 평균(139불)과 큰 격차를 보이고 있다.

원조 형태에 있어서도 비구속성원조는 ODA 관련 재화 및 용역 제공자를 선정하는데 있어 제한을 두지 않고 경쟁 입찰 방식을 채택함으로써, 원조비용을 절감하고 수원국의 관련사업 발전을 촉진하는 효과가 있다".
1979년 $\mathrm{OFCD/DAC}$ 전체의 비구속성 원조 비율은 $44 \%$ 수준이었으나, 2001년 '최빈국에 대한 ODA 바구 속성 귄고' 채택 후, 2001년 79.9\%, 2005년 918\%로 증가했는데, 우리니라의 비구속화 비율은 2005 년 기 준 $2.6 \%$ 에 불과하다 ${ }^{10}$. 정부는 한국기업의 해외 진출 을 위해서는 구속성 원조를 중심으로 대외원조를 할 수 밖에 없다는 논리를 펼치는데, 이것은 우리나라의 대외원조 기본 원칙이 우러 기업의 해외진출에 있다는 것을 의미한다. $\mathrm{EDCF}^{\varpi}$ 가 설립된 이래 삼성, 대우, 현 대 등 3 대 재벌이 전체 기금의 $53.1 \%$ 를 구속성 원조의 수혜를 받았다.

지난 10 월 이명박 대통령은 세계지도자포림에서 "이 제 대한민국은 국력과 국제적인 위상에 맞게 국제사회 에 기여할 것입니다. 대한민국은 $\mathrm{ODA}$ 를 착실히 늘려, 오는 2012년에는 $\mathrm{OECD} / \mathrm{DAC}$ 에 정식으로 가입하게 됩니다. '받는 나라' 에서 '구는 나라'로, '따라가는'나 라에서 '이끄는' 니라로 나아갈 것입니다. 그래서 인 류의 번영과 세계 평화에 기여하고 자구촌이 당면한 문제들을 해결하는데 앞서 나갈 것 입니다.” 나고 밝힌 바 있다 ${ }^{15}$. 그러나 지난 9월 한국을 방문한 에크하르트 도이처 $\mathrm{OECD/DAC}$ 의장에 따르면 한국은 여전히 따 라가는 니라이며, 그마저도 원조의 철학과 원칙, 시스 템을 대대적으로 재편 해야 한다. 그는 원조체제의 분 산, $\mathrm{ODA}$ 기본법 부재, 높은 구속성 원조비을 등 우러

7)손혁상, [우디는 왜 ODA에 주목하는가 ], 2006,5,25잠여연대.

8)구관희, 양영미 외, [한국 ODA의 실태와 개혁방안 연구], 288 쪽, 2007.

9)구속성 원조린 원조에 필요한 공사를 자국기업이 참뎌할 수 있도록 보잡하는 것.

10) 외통부, "우리나라 대외원조 현홤 및 정책 방항", 2008.4.8.

11) 1987년 대외겅제협 력기금(EDCF) 참설: 1987년 개 도국에 대한 양허성 차관 지원을 위해 300 억 원을 출언 한국수출입 은햄에 대외겅제협 력기금(EDCF Econorric Deve opmer- Coooeration Fung)은 조성하여 유상원조 본격 실시.

12) 2015 넌 한국의 공적개발원 조(ODA) 규모가 30 억 달러가 독표이다 . 
니라 ODA 정책의 문제점을 조목조목 지적했다. 한국 은 30 여개의 정부부처와 지방조직이 개발협력 활동에 참여하고 있는데 너무 분산되어 있다는 것이다. 이것 은 개빌협력 정칙 전반을 총괄하는 단일 조직이 필요하 다는 것을 의미한다. 조직개편과 ODA 정책 전빈에 대 한 체질 개편 없이는 10 년이 지나도 결코 '이끄는' 나 라가 될 수 없을 것이다. 그렇다면 -이리나라의 ODA에 서 기후변화 대응 분야는 어떻게 진행되고 있는 지를 산펴보자.

\section{1. 기후변화 대응 지원의 원칙 수립 필요}

우리징부의 $\mathrm{ODA}$ 징책의 혼신은 기후변화 분야에서도 그대로 나타난다. 총리실은 2009년 '동아시아 기후변 화 파트너십 추진 에산으로 400 억 원을 배정하였다. 그러나 국회에서는 이 예산이 기획 재정부의 대외경제 헙력기금이나 한국국제헙력단의 ODA 예산과 중보된 다는 지적을 헸다. 이 예산은 지난 7월 G8 확대정상회 담에서 대통령이 동아시아 기후 파트너십 발족에 맞춰 2 억 달더 규모의 협력사업 추ㅈㅣㅣㄴ을 제안한 데 따른 $\mathrm{ODA}$ 사업이다. 징부는 향후 5 년간 2 읙 덜러 규모의 재원을 조성해, 동아시아 지역에서의 경제성장과 기후 변화에 대처하기 위한 '동아시아 기후변화 파트너삽' 출범을 준비하고 있다. 그너나 동아시아 기후변화 파 트너쉽이 정확하게 어떤 역할을 하고 누구와 함께 할 것인가에 대해서는 충분히 논의되지 않았다.

이런 상황에서 지식경제부와 에너지관리공단도 개발 도상국의 기후변화 내응을 지원하기 위해 "08년 온실 가스감추 국제지원사업’ 을 시작했다. 약 200익원(약
1,500 만 달러, 08년 횐율기준) 규모로 기후변화협약서 상의 Non-Annex I 국가에 1) 에너지 효율적 이용- 등 을 통한 온실가스감축사업, 2) 글로벌 서탄소 경제사 회 확산을 위한 신재생에너지 사업, 3) 개도국 능력향 상을 위한 국제기구 뚜는 딘체 등과의 공동사업을 지 원한다는 것이다. $\mathrm{ODA}$ 를 늘리는 것만이 문제가 아니 다. ODA를 통해 개도국의 기후변화대응을 어떻게 호 율적으로 지원할지에 대한 원칙을 먼저 수립하고, 누 가 그 일을 하기에 가장 적임인지를 핀단하고 체계를 만들어야 한다. 현재로써는 '저탄소 녹색성장' 의 흐름 에 편성해 총리실도 시식경제부도 에너시관리공단도 각각 사업부터 시작하고 있다. 이렇게 해서는 수원국 에게 실질직인 도움이 되는 프로그램이 될 수가 없다.

\section{2. $\mathrm{ODA}$ 를 이용한 에너지 자원 개발 - 자원 ODA에서 환경 ODA로}

유가와 원자재가격이 급상승하면서 친연자원을 둔러 싼 경쟁이 이미 분쟁을 야기하고 있다. 기후변화는 이 너한 분쟁을 더 악화시키게 될 것으로 보인다. 느래서 인지 정부가 ODA를 에너지자원 확보를 위한 수단으 로 활용하려는 움직임이 인고 있다. 자원개발의 이권 을 획득하기 위한 선심형식으로 제공되는 것이다. 대 외원조는 투사에 대한 이익환수 개념을 벗어나야 한 다. 단기간에 이이을 환수하겠다는 생각으로 접근해서 는 인되는 것이다. 특히 정부는 외교에 있어서 자원외 교', '국익', '실용외교' 에 대한 단어를 남발하는데, 이 런 표현 자체가 받아들이는 수원국의 입장에서는 달갑 지가 않다. $\mathrm{ODA}$ 를 이야기 하먼서 지나치게 ‘국익을 강조하는 것도 문제라고 할 수 있다. 
외교통상부가 국회에 제출한 〈에너지 자원 외교전략 및 주요실적>에 보면, 외교통상부는 국내 에너지 정 책의 선진화 및 체계화', '에너치의 안정적 확보 및 다 원화', '에너지 외교를 통한 동북아 안징에 기여' 라는 세 가지를 목표로 선정헸다. 추진계획 두 번째 항목으 로 "에너지 자원 부국과 전략적 에너지 외교 추진"을 설정하견서 “중동과 동남아 국가와 공고한 헙력관계 를 유지하고, 세부적으로는 고위인사 교류 활성화와 ODA 제공”을 명시하고 있다. 이것은 최빈국이나 저개 발국가에 대한 인도적 지원(ODA)은 국제사회의 책임 있는 일원으로써 당연한 의무임에도, 우리 정부는 $\mathrm{ODA}$ 를 자원개발을 위한 기업의 상업적 이권과 연계 하겠다는 것이다. 이에 대해 경제징의실천연합은 “ODA를 자원외교를 위한 수단으로 활용해 자원부국 인 중동과 아프리카로 집중할 것이 아니라 잦은 분쟁 으로 빈곤과 인권탄압에 시달리는 수원국의 경제사회 빌전과 지속가능성을 위해 지원해야 한달. "는 성명서 를 반표한바 있다.

시난 11 월 12 일 유명환 외교통상보 장관은 71 개 국내 자원개빌업계를 대표하는 해외자원개빌협회 회장과 업무협력 약정을 헸다. 약정상 주요 협력 내용에는 공 적게발원조(ODA) 공여 검토 협조' 조항이 들어가 있 다. 최근 한 경제 신문의 칼럼에 실린 "공적개발원조 $(\mathrm{ODA})$ 는 일거양득 사업"이라는 칼럼은 외통부의 정책 방향과 인치한다.

“우리가 개도국에 ODA를 통해 장비와 물자를 제공하 다 보면 그 나라 산업 구조가 한국형으로 정착된다. 그
니라의 경제 발전을 도와주면서 우리니라의 설비를 수 출하는 환경을 자연스럽게 조성하는 것이다. 이는 분 명히 서로에게 득이 되는 윈원(win-win) 전략임에 틀 림없다. 지금부터라도 $\mathrm{ODA}$ 를 적극 활용하자. 최근 임 청난 외화를 굵이모은 원유수출국과 자원 부국시장을 공략해야 한다. $\mathrm{ODA}$ 를 이용-해서 한국에 대한 우호적 이미치를 조성하고 -우리 설비로 자원 북ㄱㄱㅇㅢ 산업화를 선도해야 한다."

여전히 우리 정부와 오피니언 리더들이 $\mathrm{ODA}$ 를 바라 보는 관점은 '투사한 만큼 얻어 낸다’ 라는 경제적 관 전에서 벗어나지 못하고 있음을 보여준다. ODA를 이 용해 자원을 획든한다는 징책에 대해 서는 검토가 푈요 하며, '자원 $\mathrm{ODA}$ ' 에서 '환경 $\mathrm{ODA}$ 로 전환해 나가야 한다. 현재 $\mathrm{KOICA}$ 에서는 우리의 ODA가 수원국의 환 경에 어떤 영향을 비치는지에 대한 환경영향평가 모 니터링' 에 관한 연구를 하고 있다. 사안의 중요성에 비 해 이러한 연구가 늦게 진행되긴 헸지만 지금이라도 '환경 $\mathrm{ODA}^{\prime}$ 에 대한 원칙과 체계를 갖춰나가야 한다.

\section{3. 적응시스템에 대한 배려}

기후변화에 있어 더욱 절실한 도움을 필요로 하는 것 은 적응 분야라고 할 수 있다. 이를 위해서는 전문성과 지역에 대한 이해가 필수적이다. 개도구, 주민들과 일 체가 되어 대비 시스템을 마련하고, 그때 필오한 요소 들을 지원해야 한다. 정부와 시민사회, 기업, 대학이 참어하는 파트너쉽을 마련해서 접는할 필요가 있다.

13)경실련, "자원 - 에니 지 외교를 위한 공적개반원 조(ODA이 시용을 경계한다 ,", 2008.3.12. 
우리 정부도 ODA를 통해 수원국이 기후변화적응 시 스템을 갖추도록 지원해야 한다.

\section{V. 북한의 기후변화 대응 지원}

한반도에서도 온난화는 빠른 속도로 진행되고 있다. 남 한의 기온은 지난 20 세기 100 년간 1.5 도 상승(권원태, 백희정 외, 2005 : 216 쪽)헸으며, 북한은 같은 기간 1.9 도 상승(송경란, $2007: 24$ 쪽)한 것으로 니타났다. 세계 전체의 온도 상승에 비해 2 배가 넘는 빠른 속도로 상승 하고 있는 것이다. 한반도라는 지리적 공간에저 남과 부은 기후변화에 있어 공동의 운명체라고 할 수 있다. 환경정책평가연구원에서 지구은난화에 의한 해수면 상승과 조석, 태풍해일에 의한 해수면 상승효과를 고

\section{〈그림 4〉 전국아열대 기후예측도}

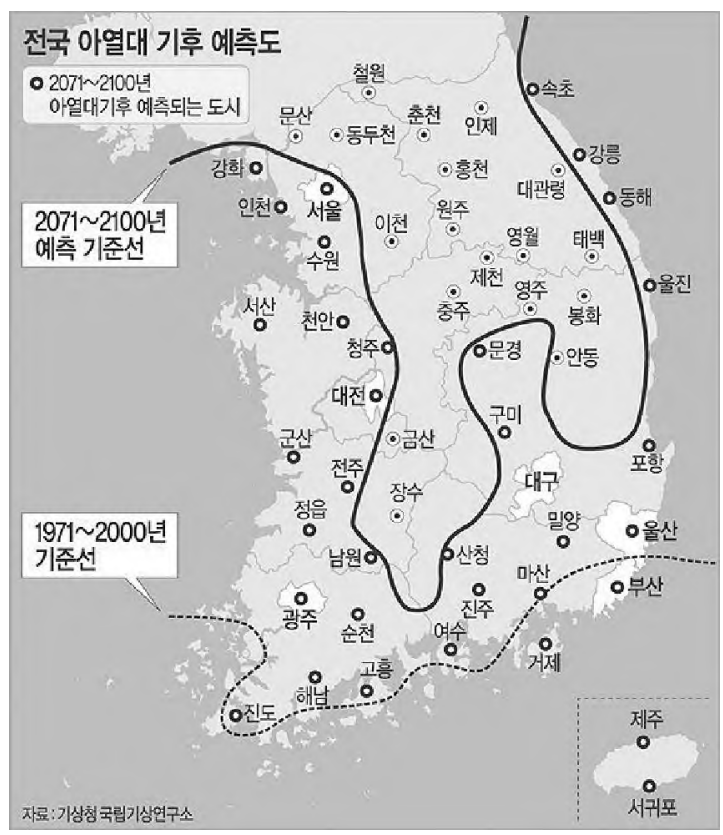

※ 출처 : 기상청 국럽기상연구소
려해 작성한 시나리오 중에서 해수면이 $1 \mathrm{~m}$ 상승하면 한반도 최대 범람 가능 면적은 약 $2,643 \mathrm{~km}^{2}$ 로서 한반도 전체 면적의 약 $1.2 \%$ 이며, 취약시대에 거주하는 인구 는 전체 인구의 약 $2.6 \%(1,255,000$ 명 $)$ 인 것으로 나타 났다(즈광ㅇㅇㅜ, 김지혜, 정휘천 외, $2002: 149$ 쪽). 지리 적으로는 서해안이 남해안과 동해안에 비하여 횔씬 더 취약한 것으로 나타났으며, 서해안 중에서도 눅한이 남한보다 더 취약한 것으로 나타났다.

\section{VI. 마무리}

지구촌은 기후변화를 해결하지 읺고서는 각국이 다 함 께 합의한 밀레니엄목표를 달성할 수가 없다. ODA와 기후변화에 대한 철학과 원칙을 바로세우고, 프로그램 을 개발하고, 인재를 만들고, 평가하는 시스텐을 갖추 야 한다. 또한 ODA 자체가 기후변화를 가속화 시키는 방향으루 진행되어서는 인 된다.

우리가 아무런 조치를 취하시 않는다면 기후변화는 더 악화될 것이고, 가난한 나라와 가난한 나라에 살고 있 는 가난한 사람들이 가장 큰 영향을 받게 된다. 공통적 이면서도 서로 차벌화 된 노력에 있어서 우리니라도 예외가 아니다. 특히 우니나나는 북한의 기후변화 대 응에 있어서도 진지하세 접근을 해야 한다. 기후변화 에 대한 대처는 다음세대로 미뤄서는 안된다. 기후변 화가 걷잡을 수 없는 상황으로 확대되기 전에 우리세 대에서 해결해야 한다. 그렇게 하기 위해서는 대외원 조 체계에 내한 개혁이 필수적이녀, ODA와 기후변화 에 대한 보다 깊이 있는 논의가 진행되어야 할 것이다. 


\section{[ 참고 문헌 ]}

1. 국내문헌

구관희, 양영미 외(2007), 한국 ODA의 실태와 개혁방안 연구.

경실련(2008.3.12), 자원· 에너지 외교를 위한 공저개발원조O DA)의 사용을 경계한다.

박은호(2008.07.05), 기후변화대응안하면 환경난민 됩니다, 조선일보.

손혁상(2006.5.25), 우리는 왜 ODA에 주목하는가, 침여연대.

외통부(2008.4.8), 우리나라 대외원조 현황 및 정책 방향.

Walker, Gabrielle and King, D. A. (2008). 핫 토픽. - 기후변화 생존과 대응전략, 조윤커뮤니케이션.

\section{2. 외국문헌}

The Guardian, February $(7,2008)$, UK warms to Climate change aid. 